\title{
Biodiversity Governance and Management in Pakistan: a Way Forward Through the China-Pakistan Economic Corridor
}

\author{
Akhtar Hussain Lashari' ${ }^{1,2}$, Wei Li ${ }^{1 *}$, Mabroor Hassan³ ${ }^{3}$ Ghulam Nabi', \\ Prince T. Mabey ${ }^{1}$, Mohammad Morshedul Islam ${ }^{1}$, Wajid Rashid ${ }^{1}$, \\ Safdar Ali Ujjan ${ }^{5}$, Khadim Hussain Memon ${ }^{5}$ \\ ${ }^{1}$ School of Environment, Beijing Normal University, Beijing 100875, China \\ ${ }^{2}$ Department of Education, Sukkur IBA University, Airport Road, Sukkur 65200, Pakistan \\ ${ }^{3}$ Green Environ Sol (Private) Limited, Islamabad 67337, Pakistan \\ ${ }^{4}$ Key Laboratory of Animal Physiology, Biochemistry and Molecular Biology of Hebei Province, \\ College of Life Sciences, Hebei Normal University, Shijiazhuang 050024, China \\ ${ }^{5}$ Department of Zoology, Shah Abdul Latif University, Khairpur Mir's 66111, Pakistan
}

Received: 23 April 2020

Accepted: 11 August 2020

\begin{abstract}
Pakistan is rich in biodiversity, but for several reasons, it has not paid enough attention to biodiversity conservation and management. Furthermore, the country's biodiversity action plan (BAP) for biodiversity issues is limited. This study aimed to assess the considerations in the BAP regarding biodiversity, progress, and issues in the implementation of the China-Pakistan Economic Corridor. The poor implementation of the BAP is the result of the failure of authorities to enforce Pakistan's laws in the country as well as cross-border China-Pakistan Economic Corridor. In this regard, the knowledge, attitudes, and perspectives of the officials of different environmentally concerned departments in Pakistan needed to be reviewed. Their opinions on Pakistan's BAP were determined. A questionnairebased survey of the perceptions about Pakistan's BAP was conducted. According to the majority of the respondents, the reasons for weak biodiversity governance were unclear targets and goals that resulted from poor institutional coordination (72\%), unclear responsibilities $(56 \%)$, and insufficient advisory guidelines (68\%). This result demonstrates the country's failure to fulfill its commitments to the Convention on Biological Diversity by implementing the BAP. Even the country's environmental authorities did not agree to consider biodiversity or the implementation of BAP in the China-Pakistan Economic Corridor route, and no biodiversity-related survey or biodiversity-related training has been implemented. Therefore, improvement in biodiversity governance can counter some of the pressures
\end{abstract}

*e-mail: weili@bnu.edu.cn 
and can enhance not only the biodiversity status of the country but also the state of the China-Pakistan

Economic Corridor.

Keywords: biodiversity action plan, convention on biological diversity, biodiversity governance, China-Pakistan economic corridor, Pakistan

\section{Introduction}

Biodiversity conservation governance is a major contemporary issue in all developing countries [1]. The strength of biodiversity conservation and management in developing countries may be hard to assess because most countries do not have systems for monitoring biodiversity [2]. The prerequisite to promote sustainability is currently globally identified, and a set of global goals has been adopted on this basis for the eradication of poverty, protection of the planet, and guaranteed prosperity for all [3]. Pakistan is one of the countries with the richest biodiversity [4] and must be given importance [5]. In line with this consensus, Pakistan developed its first biodiversity action plan (BAP) in 1999 under the Convention on Biological Diversity (CBD) [6] to fulfill the requirements of the international community. Article 6 of $\mathrm{CBD}$ requires the development of national strategies, plans, or programmes, along with the incorporation into the sustainable use of biodiversity. In 2010, the CBD meeting developed the Strategic Plan for Biodiversity 2011-2020 to achieve the two Millennium Development Goals (MDGs), 14 in general, and 15 (Life on Land) in particular [7, 8]. Unfortunately, its commitments and objectives were not met because of weak biodiversity governance, institutional frameworks, low literacy rates, poor infrastructure, small budgets, low political clout and insufficient policy or strategic implementation [9], which were primarily due to weak institutional arrangements for the implementation of CBD at the national and regional levels [10].

Biodiversity governance within the country is currently feeble, as is that for the China-Pakistan Economic Corridor (CPEC), a Chinese megaproject affecting the country's biodiversity [11]. Pakistan has paid no attention to this issue, and the commitment to CBD has not been fulfilled. Thus, this study aims to assess the considerations in the BAP in Pakistan and CPEC with regard to biodiversity, progress, and issues. The current paper is based on the results of perception analysis of environment department officials in Pakistan and explores the current scenario on biodiversity governance, BAP progress, and its issues in the country and throughout the CPEC. To date, no study of BAP-related knowledge has been carried out in Pakistan. Pakistan is already handling biodiversity issues and has overloaded its responsibilities and biodiversity protection burden by participating in the CPEC megaproject. This project is under the Belt and Road Initiative (BRI), which has ecological impacts associated with the specific types of development projects, especially land-use changes, landscape connectivity and emissions [12], and poses a great risk to biodiversity; the areas of concern are habitats of threatened and endangered species that are not found in the rest of the world [13]. CPEC is a part of the BRI, which also affects the biodiversity of coastal marine areas in the Arabian Sea, Gwadar Port [14] and northern areas $[15,16]$ that provide habitat for notable mammals on the International Union for the Conservation of Nature (IUCN) red list [11]. The melting glaciers in the northern region $[15,17,18]$, along with population pressures [19], are also the result of the CPEC.

Moreover, Pakistan is already grappling with some of the external pressures on biodiversity, such as habitat fragmentation that affects avian species [20], turtles [21], and the brown bear [22]. Indeed, illegally hunt endangered species throughout Pakistan [23, 24]. Thus, corridors and roads provide locals with hunting opportunities, which raises animal mortality and escapes [25]. Another significant problem is the shifting of polluting industries from China to Pakistan, where environmental standards are weak [26, 27]. So, in this concern, China launched two programmes in 2017 to protect the biodiversity of cross-border countries. One is the Guidance on Promoting Green Belt and Road, which aims to enhance green development along with protection of the environment at BRI projects through environment impact assessments (EIAs), and the second is the Road Ecological and Environmental Cooperation Plan, which aims to endorse the Green Belt and Road for Pakistan. Ma Keping, an expert in biodiversity, presented maps showing how corridor construction could affect some of Pakistan's fragile ecosystems, and he suggested that biodiversity corridors should be established, and localized action plans should be developed to promote conservation [28]. However, not all these steps are viable, and further indications of the tools or institutional mechanisms for doing so have not been provided. Meanwhile, the whole world is aspired to overcome biodiversity problems, such as fragmentation, overfishing and wildlife illegal hunting [19].

Pakistan has weak biodiversity management or policies for the CPEC road route. Moving towards ecological sustainable development, improving national biodiversity governance, and raising social awareness for biodiversity conservation are urgently needed. Biodiversity should be the core value of CPEC. Negligible studies on BAP implementation and the obstacles posed by the CPEC has been conducted previously. In this study, the present BAP implementation scenario and its outcomes in the country and to CPEC will be explored. 


\section{Material and Methods}

\section{Study Areas}

The data were collected from all provincial entities and relevant departments for biodiversity, management, and implementation across Pakistan (see Fig. 1). The questionnaire survey was constructed from different schools of thought, such as those of concerned state departments, technical experts, and academics. The departments consulted for data collection included the Environmental Protection Agency (EPA)-Azad Jammu and Kashmir (AJK), Baluchistan Forestry and Wildlife, EPA-Baluchistan, EPA-Islamabad Capital Territory (ICT), EPA-Khyber Pakhtunkhwa (KP), EPA-Punjab, EPA-Sindh, Sindh Wildlife Department, Sindh Forest Department, Forestry, Wildlife, and Environment Department Gilgit-Baltistan as well as professors at ICT.

\section{Data Collection and Analysis}

The primary data sources used for the analysis included 90 questionnaires. The primary data were collected using a questionnaire survey of environmental ministries, related departments, environmental experts, academics, legal and technical experts, nongovernmental organizations (NGOs) representatives, and independent observers across the country. The questionnaire comprised three major sections, namely, biodiversity considerations, biodiversity action plans and assessments, and biodiversity governance in
Table 1. Demographic characteristics of respondents $(n=90)$.

\begin{tabular}{|c|c|}
\hline Demography: & (\%) response \\
\hline \multicolumn{2}{|c|}{ Gender } \\
\hline Male & (54) \\
\hline Female & (46) \\
\hline \multicolumn{2}{|c|}{ Age category } \\
\hline $20-30$ & (12) \\
\hline $30-40$ & (60) \\
\hline $40-50$ & (20) \\
\hline$>50$ & (8) \\
\hline \multicolumn{2}{|c|}{ Educational Level } \\
\hline Bachelor & (30) \\
\hline Master & (43) \\
\hline Doctorate & (27) \\
\hline \multicolumn{2}{|c|}{ Experience (Years) } \\
\hline$<5$ & (36) \\
\hline $5-10$ & (24) \\
\hline $10-20$ & (32) \\
\hline$>20$ & (8) \\
\hline
\end{tabular}

Pakistan and for the CPEC. The demographic profiles of the respondents were matched with the survey types in these areas. The program was administered to a random

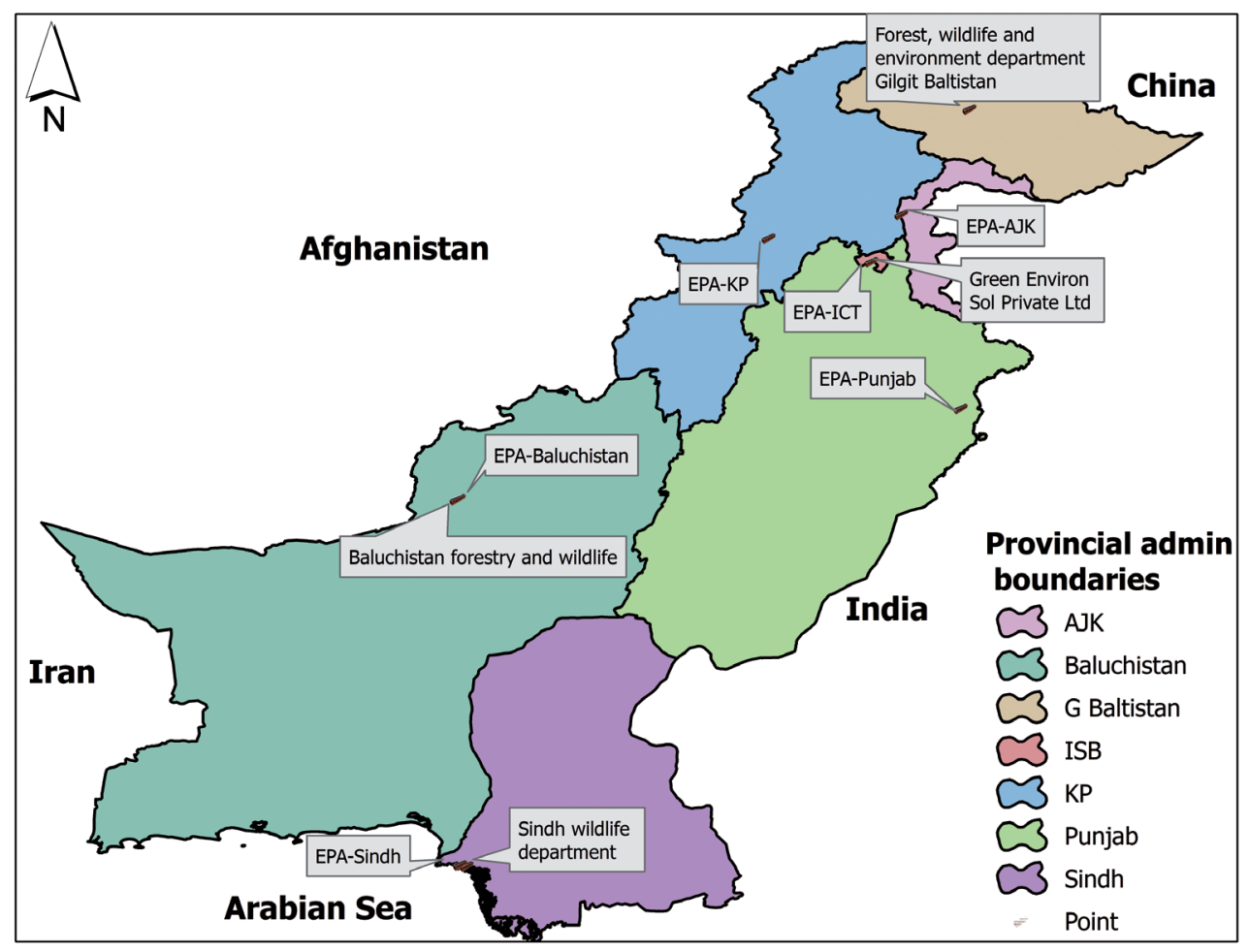

Fig. 1. Map of Pakistan showing the locations of surveyed institutions. 
sample of respondents. A total of 15 questionnaires were used for each provisional entity, including AJK, Baluchistan, Gilgit-Baltistan, KP, Punjab, and Sindh. The data were analysed using SPSS (IBM ${ }^{\circledR}$ SPSS ${ }^{\circledR}$ Statistics Version 20) and Origin (Origin ${ }^{\circledR} 2018$ Version 95E) software to present an actual scenario of biodiversity management and governance in Pakistan.

\section{Results and Discussion}

\section{Demographic Characteristics of the Respondent}

Table 1 shows the demographic characteristics of the respondents during the survey. The majority (54\%) of the respondents were males, $60 \%$ were within the age range of 30-40 years, with tertiary education (30\%) and $10-20$ years of experience $(32 \%)$.

\section{Overall Perceptions for Biodiversity Consideration in Pakistan}

Surveys of user perceptions and attitudes are critical for understanding the effectiveness and shortcomings of natural resource biodiversity governance, which cannot be achieved through prohibition alone, as many studies have demonstrated [29]. The overall knowledge about biodiversity consideration and implementation suggests that the national BAP and CPEC territory are often the most interesting aspects of weakness-based research. Studies have shown the lack of enforcement of environmental laws. Pakistan's biodiversity domain includes several significant areas, such as wildlife, fisheries, forestry, and agriculture. Although sectoral policies have been developed for such areas, governance and management remain weak. The respondents believed that environmental agencies, departments, and law enforcement territories at the national level lack urgency. Although biodiversity is not a personal matter, they stated that it is only the responsibility of the state.

Pakistan is rich in biodiversity, but, for a variety of reasons, it has not paid sufficient attention to biodiversity. The lack of political will, low environmental awareness in ministries, weak environmental enforcement, and insufficient mandatory provisions related to the implementation of BAPs are the leading causes at the country level. According to the respondents, the low concern of the people for biodiversity can be attributed to ineffective biodiversity laws (30\%) and little community-based training (60\%) by government authorities. Apart from about a dozen of NGOs activities, a substantial number of communitybased organizations have partnered with donor-funded environmental projects, created community-level awareness of environmental issues, and have initiated commendable pilot projects in forestry, wildlife, and other related sectors. Other factors were the lack of political will (16\%), although there are biodiversityrelated ministries that consider biodiversity issues $(56 \%)$ in Pakistan.

Thus, the current situation for environmental laws is scrawny, as reported by $74 \%$ of the respondents. Overall implementation has been unsatisfactory since the BAP was approved [30]. As a result, the institutional framework for biodiversity was also accused of not being strong enough to run in Pakistan by approximately half of the respondents, as shown in Fig. 2. Biodiversity laws and practices should be seriously taken into consideration as they are vital to biodiversity conservation [31].

Although Pakistan has developed biodiversity governance and a central pivot, policy implementation remains weak and relies mainly on international organisations and timely collaborations. Weak governance and institutional frameworks, low literacy rates, poor infrastructure, small budgets, low political clout, and insufficient policy or strategic implementation tools are barriers in conservation and management of biodiversity in Pakistan.

\section{Biodiversity Action Plan and Its Effectiveness in Pakistan}

Although Pakistan has developed BAPs to fulfil the requirements of international commitments, it is

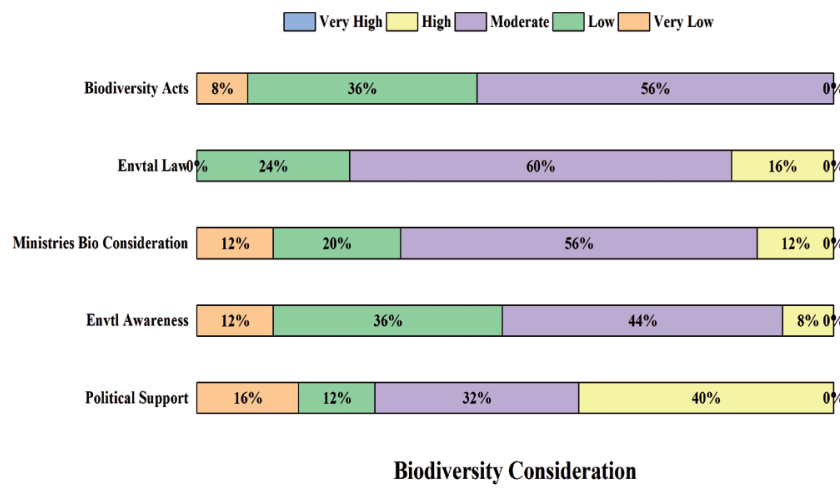

Fig. 2. Biodiversity Consideration.

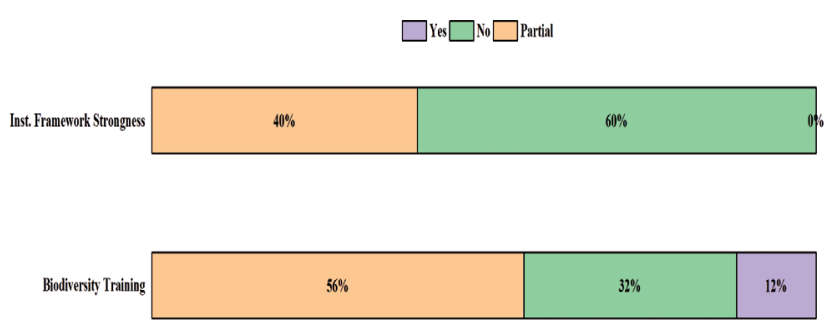

Biodiversity Consideration 
Table 2. BAP Adaptation Issues $(n=90)$.

\begin{tabular}{|c|c|c|c|c|c|c|c|c|}
\hline Question: & & $\begin{array}{l}\text { Strongly } \\
\text { disagree }\end{array}$ & Disagree & Neutral & Agree & $\begin{array}{l}\text { Strongly } \\
\text { agree }\end{array}$ & Mean & $\begin{array}{c}\text { Std. } \\
\text { Deviation }\end{array}$ \\
\hline \multirow[b]{2}{*}{ Political will: } & Weak political support: & 0 & $(20 \%)$ & $(8 \%)$ & $(48 \%)$ & $(24 \%)$ & 3.760000 & 1.051982 \\
\hline & $\begin{array}{c}\text { Unclear environmentally sustain- } \\
\text { able policies and objectives or } \\
\text { targets: }\end{array}$ & 0 & $(20 \%)$ & $(12 \%)$ & $(60 \%)$ & $(8 \%)$ & 3.560000 & 0.916515 \\
\hline \multirow{2}{*}{ Legal mandate: } & $\begin{array}{c}\text { Lack of mandatory Biodiversity } \\
\text { law's provisions: }\end{array}$ & 0 & $(16 \%)$ & $(8 \%)$ & $(60 \%)$ & $(16 \%)$ & 3.760000 & 0.925563 \\
\hline & Insufficient enforcement: & 0 & 0 & $(12 \%)$ & $(68 \%)$ & $(20 \%)$ & 4.080000 & 0.571548 \\
\hline \multirow{2}{*}{$\begin{array}{l}\text { Environmental } \\
\text { institutions } \\
\text { capacity }\end{array}$} & Poor institutional co-ordination: & 0 & $(4 \%)$ & $(8 \%)$ & $(72 \%)$ & $(16 \%)$ & 4.000000 & 0.645497 \\
\hline & $\begin{array}{l}\text { Unclear responsibilities and } \\
\text { competences: }\end{array}$ & 0 & $(12 \%)$ & $(20 \%)$ & $(56 \%)$ & $(12 \%)$ & 3.680000 & 0.852447 \\
\hline \multirow{3}{*}{$\begin{array}{l}\text { BAP } \\
\text { implementation: }\end{array}$} & Ineffective public attention: & 0 & $(4 \%)$ & $(20 \%)$ & $(52 \%)$ & $(24 \%)$ & 3.920000 & 0.909212 \\
\hline & $\begin{array}{l}\text { Lack of systematic review } \\
\text { criteria: }\end{array}$ & 0 & $(4 \%)$ & $(12 \%)$ & $(68 \%)$ & $(16 \%)$ & 3.920000 & 0.812404 \\
\hline & Weak follow-up and monitoring: & 0 & 0 & $(32 \%)$ & $(48 \%)$ & $(20 \%)$ & 3.880000 & 0.725718 \\
\hline \multirow{3}{*}{$\begin{array}{c}\text { Technical } \\
\text { know-how: }\end{array}$} & Insufficient advisory guidelines: & 0 & $(4 \%)$ & $(24 \%)$ & $(68 \%)$ & $(4 \%)$ & 3.720000 & 0.613732 \\
\hline & $\begin{array}{l}\text { Uncertain and unreliable method- } \\
\text { ologies: }\end{array}$ & 0 & $(4 \%)$ & $(12 \%)$ & $(68 \%)$ & $(16 \%)$ & 3.960000 & 0.675771 \\
\hline & Lack of training support: & 0 & 0 & $(12 \%)$ & $(60 \%)$ & $(28 \%)$ & 4.160000 & 0.624500 \\
\hline \multirow{2}{*}{$\begin{array}{l}\text { Legal basis for } \\
\text { BAP in Pakistan }\end{array}$} & Exclusive provisions & 0 & $(20 \%)$ & $(24 \%)$ & $(44 \%)$ & $(12 \%)$ & 3.480000 & 0.962635 \\
\hline & Integrated with other legislation & $(4 \%)$ & $(20 \%)$ & $(16 \%)$ & $(32 \%)$ & $(28 \%)$ & 3.600000 & 1.224745 \\
\hline
\end{tabular}

void to achieve the targets owing to weak biodiversity governance and improper BAP implementation [9]. The BAP, which was developed by the Biodiversity Working Group, aims to improve biodiversity and protected areas. Under the BAP, numerous legislations address biodiversity issues, such as the 2018 Climate Change Act, the 2018 National Wildlife Policy (draft), the 2017 Plant Breeders' Rights Rules (draft), the 2016 Plant Breeders' Act, the 2012 Climate Change Policy, the 2005 Pakistan Environmental Policy and the 2015 National Forest Policy, the Fisheries and Aquaculture Policy 2006 [32]. Most research respondents recognized that apart from many factors and obstacles, the main hindrances to BAP implementation are 1) the lack of systematic review, 2) weak follow-up, and 3) weak monitoring and insufficient advisory guidelines, as shown in Table 2.

The implementation of the BAP has been weak since the relevant departments do not apply the legislation in Pakistan's territories. Provincial EPAs have power and jurisdiction according to the $18^{\text {th }}$ amendment for biodiversity concerns [33]. Indeed, the lack of cumulative coordination between provincial and federal environmental departments could not be ignored.

The Fisheries and Aquaculture Policy 2006 govern the Sindh and Baluchistan marine and freshwater fisheries in Pakistan, along with the initial stages of shrimp farming and aquaculture activities [34]. The
Baluchistan Sea Fisheries Act 2014 is trying to fulfil the commitment to BAP [35]. So, overall, these policies were regarded as ineffective by $68 \%$ of respondents, as the study indicated for forestry, wildlife and fisheries policies in Pakistan. Even the majority of concerned officials were moderately informed of all biodiversity relevant laws and policies, as shown in Fig. 3. The wildlife policy draft for 2018, which includes Sindh's policy input and expected implementation rate, is still on hold. Although a provisional wildlife board for policy formulation exists [36] but has low performance. In this regard, globally, a conference of parties (CoP) was held in 2010 at Nagoya in Aichi Prefecture, Japan, to strengthen the biodiversity area, and a strategic plan for biodiversity was adopted for the 2011-2020 period, with five strategic objectives and 20 Aichi Biodiversity Targets. So, in Pakistan the goals have been accomplished somewhat, but it was long overdue, as this study shows that half of the respondents reported that the priorities and objectives were vague due to weak institutional coordination (72\%), unclear responsibilities $(56 \%)$ and insufficient advisory guidelines (68\%) in the country.

In general, weak institutional coordination and coherence caused the proper implementation of the forest, wildlife, and fisheries sectors to hinder the realization of BAPs. The marine and freshwater fisheries policies in Sindh and Baluchistan are outdated and require technical review. 


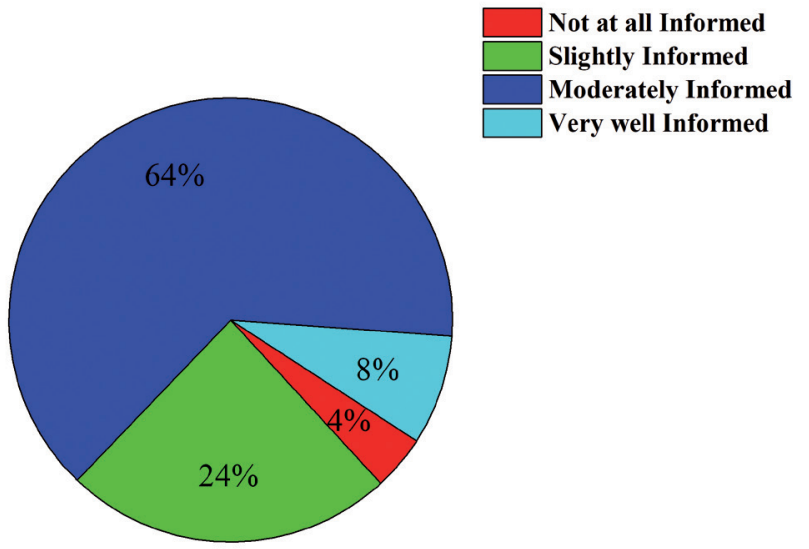

Biodiversity Laws Awareness

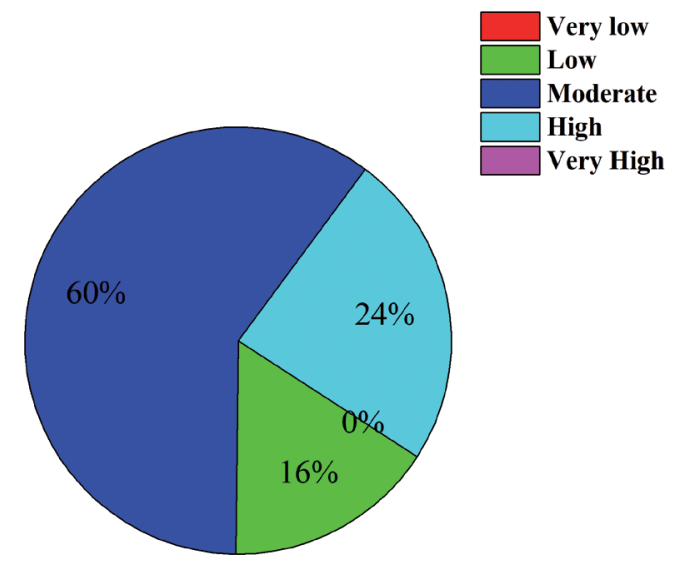

Forest, Wildlife and Fisheries Effectiveness

Fig. 3. Effectiveness and awareness of forest, wildlife and fisheries laws.

\section{Biodiversity and Sustainable CPEC}

CPEC is a corridor that passes only through Pakistan [37] and comprises the northern mountains, with equal participation in economic development and biodiversity; hence, damage to biodiversity is likely $[15,38]$. This region of Pakistan is inhabited by approximately half of the state's biodiversity, and the findings of the present study suggest that more than half of the respondents (68\%) believe that the CPEC will adversely impact biodiversity. In spite of its negative aspects, no institution, entity, or individual has raised severe questions or opinions about biodiversity degradation along the CPEC line for unknown reasons. Even our environmental authorities have not agreed to consider biodiversity or the implementation of the BAP along the CPEC route, and no biodiversity-related survey or biodiversity-related training has been conducted, as shown in Fig. 4. The CPEC road project provides one of the most significant opportunities and is an elegant programme but does not consider the environmental standards that are inadequate for territory [39]. Biodiversity assessments along the CPEC should be adequately initiated in coordination with the relevant Pakistani institutions [40]. The assessment tools, such as EIA [41], initial environmental examination (IEE), a strategic environmental assessment (SEA), and social impact assessment (SIA), have not been undertaken for this megaproject [42]. Still, now it is decided to conduct SEA mandatory before the commencement of new projects [43].

Nevertheless, these assessments will not provide further indications of the tools or institutional mechanisms for execution. Biodiversity management and policies for the CPEC road route are not sufficient to address biodiversity issues. Although China formulated the Belt and Road Ecological and Environmental Cooperation Plan in 2017 to promote the Green Belt and Road for Pakistan, it has not been meaningful to date. This argument was supported by China, which provided two documents to guide environmental protection, including the prevention of soil erosion, noise, and air pollution, and other documents on biodiversity conservation, including the protection of habitats and threatened species in conjunction with the environmental legislation and operations of all host countries [12, 44].

However, the BAP, which can strengthen weak wildlife, fisheries, and forestry policies, is not without obstacles that hinder its implementation, such as so for many reasons and tentative transboundary issues. Hence, Pakistan has not reported such an initiative thus far. An extensive dialogue amongst environmentalists and planners from China and Pakistan is needed for the review of biodiversity matters.
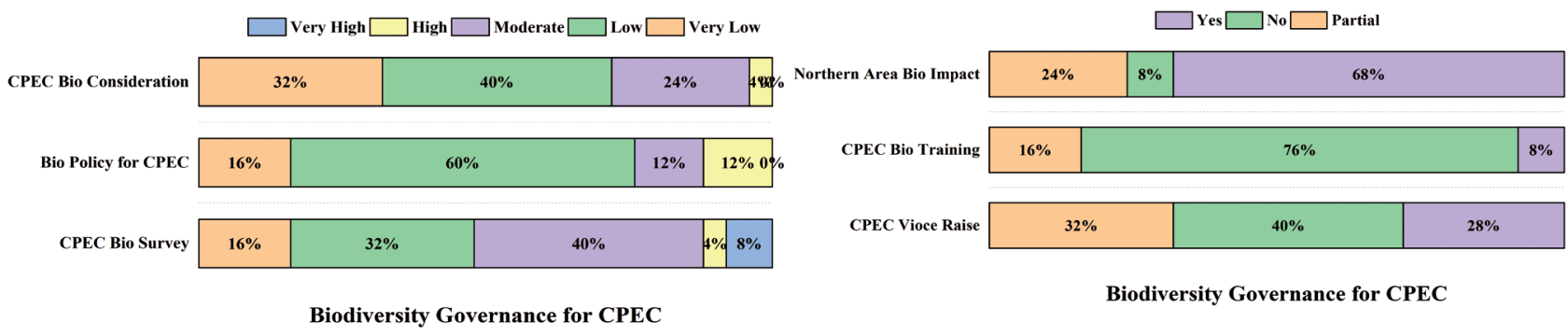

Biodiversity Governance for CPEC

Fig. 4. Biodiversity Governance for CPEC. 


\section{Conclusions}

Viable implementation of the biodiversity action plan is crucial for the accomplishment of the management goals. The BAP cannot achieve any effective biodiversity policies unless it is implemented. The country developed the BAP, but it had not been successfully implemented for various reasons, such as unclear targets and goals, poor institutional coordination, unclear responsibilities and insufficient advisory guidelines in the country. The forest, wildlife, and fisheries sectors lack compliance in the proper implementation of BAPs as a result of weekly institutional coordination and coherence, as most studies have revealed. These obstacles destabilize not only the biodiversity in the country but also transboundary CPEC biodiversity management. According to the majority of the respondents, the reasons for weak biodiversity governance were unclear targets and goals that resulted from poor institutional coordination (72\%), unclear responsibilities (56\%) and insufficient advisory guidelines (68\%). This result demonstrates the country's failure to fulfil its commitments to the Convention on Biological Diversity by implementing the BAP. Despite its benefits, the CPEC is threatening the biodiversity of the northern area with pollutionproducing projects, especially along its route. Hence, the BAP implementation is mandatory in biodiversity protection, as committed by the CBD.

\section{Policy Implications}

Various approaches are needed to strengthen the existing laws. Some collective recommendations, including field modules, biodiversity trainings or workshops for the wildlife, forest, and fisheries sectors related to CPEC, should be presented. Environmentalists and planners in China and Pakistan need a far-reaching dialogue to focus entirely on biodiversity. The proper provision of domestic and international funding to provincial departments can make the dream of sustainable biodiversity management a reality. Pakistan should review its biodiversityrelated policies by ensuring its proper implementation without compromising due to obstacles, hindrances, or political carelessness. Presented below are some of the recommended policy implications for overcoming Pakistan's BAP-related shortcomings.

- Develop, approve, and implement judicial independence for Pakistan's national biodiversity policy, which covers flora and fauna.

- Integrate biodiversity policy measures into sectoral initiatives.

- Create integrated China-Pakistan biodiversity policies to address current transboundary biodiversity losses.

- Revise, re-examine, develop active wildlife, fisheries, and forestry policies in combination with national environmental policy and climate change policy.
- Visualize and consider conservation of indigenous aquatic biodiversity in fisheries policy.

- Consider inputs of national and international policy experts to protect Pakistan's biodiversity. The input to biodiversity policy requires national and international experts without the communication gap.

- Propose community-based biodiversity management and governance systems in northern areas.

- Establish a detailed national biodiversity act to conserve both fauna and flora in Pakistan.

- Propose institutionalised systems to review emerging biodiversity policy and integrate into plans.

- Provision of efficient functionality of environmental tribunal and the green benches.

- Develop the capacity of existing biodiversity-related departments for effective biodiversity management in Pakistan.

\section{Acknowledgements}

This work was supported by the Project of Ecological Capital and Ecosystem Service Assessment, the second Comprehensive Investigation \& Study on the QinghaiTibet Plateau (No. 2019QZKK0307), supervised by the Chinese Academy of Sciences \& the Ministry of Science and Technology of China.

\section{Conflict of Interest}

The authors declare no conflict of interest.

\section{References}

1. ROE D., SEDDON N., ELLIOTT J. Biodiversity loss is a development issue. 2019.

2. DANIELSEN F., BALETE D.S., POULSEN M.K., ENGHOFF M., NOZAWA C.M., JENSEN A.E. A simple system for monitoring biodiversity in protected areas of a developing country. Biodiversity \& Conservation. 9 (12), 1671, 2000.

3. ASSEMBLY G. Sustainable development goals. SDGs), Transforming our world: the. 2030, 2015.

4. BONKOUNGOU E.G. Biodiversity in drylands: Challenges and opportunities for conservation and sustainable use. Challenge Paper. The Global Drylands Initiative, UNDP Drylands Development Centre, Nairobi, Kenya. 2001.

5. HANSON A.J., BASS S., BOUZAHER A., SAMDANI G.M., ZEHRA M. Pakistan's national conservation strategy: Renewing commitment to action. Report of the Mid-Tenrt Review. [Online] Available from http://www. nssd. net/pdf/ncsmtr. pdf [cited 14 February 2007]. f-lanis, PR and Moran, RT (1987) Managing Cultural Differences. Housten: Gulf Publishing Company. 2000.

6. GOP. Pakistan national biodiversity strategy and action plan for achieving "aichi biodiversity targets and sustainable development goals". 2017-2030. 
7. OPOKU A. Biodiversity and the built environment: Implications for the sustainable development goals (sdgs). Resources, Conservation and Recycling. 141, 1, 2019.

8. MCGOWAN P.J., STEWART G.B., LONG G., GRAINGER M.J. An imperfect vision of indivisibility in the sustainable development goals. Nature Sustainability. 2 (1), 43, 2019.

9. GOP. Pakistan 5th national report to cbd., Climate Change Division: Islamabad, Pakistan. 98, 2014.

10. WANI B.A. National forest policy review. Ministry of Environment, Local Government and Rural Development, Islamabad, Pakistan. 2002.

11. NABI G., KHAN S., AHMAD S., KHAN A., SIDDIQUE R. China-Pakistan economic corridor (cpec): An alarming threat to the biodiversity of northern pakistan. Biodiversity and Conservation. 26 (12), 3003, 2017.

12. TEO H.C., LECHNER A.M., WALTON G.W., CHAN, A. CHESHMEHZANGI F.K.S., TAN-MULLINS M., CHAN H.K., STERNBERG T., CAMPOS-ARCEIZ A. Environmental impacts of infrastructure development under the belt and road initiative. Environments. 6 (6), 72, 2019.

13. HUGHES A.C. Understanding and minimizing environmental impacts of the belt and road initiative. Conservation Biology. 2019.

14. EBRAHIM Z. China pakistan economic corridor: A boon for the economy, a bane for locals. Retrieved from Dawn: https://www. dawn. com/news/1236159. 2016.

15. NABI G., ULLAH S., KHAN S., AHMAD S., KUMAR S. China-Pakistan economic corridor (cpec): Melting glaciers - a potential threat to ecosystem and biodiversity. Environmental Science and Pollution Research. 25 (4), 3209, 2018.

16. ABID M.A. ASHFAQ. Cpec: Challenges and opportunities for pakistan. Journal of Pakistan Vision. 16 (2), 142, 2015.

17. KÄÄB A., TREICHLER D., NUTH C., BERTHIER E. Brief communication: Contending estimates of 2003-2008 glacier mass balance over the pamir-karakoram-himalaya. The Cryosphere. 9 (2), 557-, 2015.

18. GILANY S.N.A., IQBAL J. Geospatial analysis of glacial dynamics in shigar and shayok basins. 2016.

19. YU X. Biodiversity conservation in china: Barriers and future actions. International Journal of Environmental Studies. 67 (2), 117, 2010.

20. ALI A., ALTAF M., KHAN M.S.H. Winter survey of birds at keti bunder, district thatha, pakistan. Punjab Univ. J. Zool. 31, 203, 2016.

21. SAEED K., AZAM M.M., WAHAB A. Freshwater turtles of pakistan: Threats to survival and conservation challenges.

22. NAWAZ M.A. Status of the brown bear in pakistan. Ursus. $18(1), 8,2007$

23. BHAGWANDAS, Members of gulf royal families given permits to hunt protected bird, in Dawn 2019.

24. NABI G., ULLAH R., KHAN S., AMIN M., RAUF N. The asian houbara bustard (chlamydotis macqueenii): On an accelerating path to extinction? Biodiversity and Conservation. 28 (5), 1301, 2019.

25. LAURANCE W.F., GOOSEM M., LAURANCE S.G. Impacts of roads and linear clearings on tropical forests. Trends in Ecology \& Evolution. 24 (12), 659, 2009.

26. LECHNER A., TEO M.H.C., CAMPOS-ARCEIZ A. The risk to biodiversity along china's belt and road initiative (bri). 2019.
27. ASCENSÃO F., FAHRIG L., CLEVENGER A.P., CORLETT R.T., JAEGER J.A., LAURANCE W.F., PEREIRA H.M. Environmental challenges for the belt and road initiative. Nature Sustainability. 1 (5), 206, 2018.

28. IUCN D. Clear waters and green mountains - cpecsummit 2018, in Dawn. 2018.

29. MCNEILL A., CLIFTON J., HARVEY E.S. Attitudes to a marine protected area are associated with perceived social impacts. Marine Policy. 94, 106-118, 2018.

30. MOCC G.A. Pakistan national biodiversity strategy and action plan. 2015: Pakistan.

31. PATANKAR V.J. Attitude, perception and awareness of stakeholders towards the protected marine species in the andaman islands. Ocean \& Coastal Management. 179, 104830, 2019.

32. KHAN I.U., YASEEN A. Implementation of climate change convention in pakistan. Dialogue (Pakistan). 12 (4), 2017.

33. ANWAR M., JASRA A.W., AHMAD I. Biodiversity conservation status in pakistan-a review. The Pakistan Journal of Forestry. 58 (1), 39, 2008.

34. KAUSAR R. Best management practices in aquaculture in pakistan. Best Management Practices in Aquaculture. 69, 2017.

35. ALI M.R. Small-scale fisheries in pakistan. Small-scale Fisheries in South Asia. 81, 2018.

36. PAKISTAN M. Pakistan national strategy and action plan. 2014, by: MFF Pakistan and Climate Change Division, Government of Pakistan.

37. MENHAS R., MAHMOOD S., TANCHANGYA P., SAFDAR M.N., HUSSAIN S. Sustainable development under belt and road initiative: A case study of chinapakistan economic corridor's socio-economic impact on pakistan. Sustainability. 11 (21), 6143, 2019.

38. LASHARI A.H., LI W., HASSAN M., NABI G., MABEY P.T., ISLAM M.M., RIND K.H., UJJAN S.A. Biodiversity conservation in china-pakistan economic corridor region with strategic environmental assessment. Environmental Science and Pollution Research. 2020.

39. TARIQ B. Environmental impacts of cpec roadway network and mitigation techniques.

40. LEAL-ARCAS R., MORELLI A. The resilience of the paris climate agreement: Negotiating and implementing the climate regime. 2018.

41. KOUSER S., SUBHAN A.J.E.S., RESEARCH P. Uncovering pakistan's environmental risks and remedies under the china-pakistan economic corridor. 27 (5), 4661, 2020.

42. DURANI M.Q., KHAN M.B. The environmental impact of the china-pakistan economic corridor (cpec): A case study. Abasyn University Journal of Social Sciences. 11 (1), 2018.

43. KHAN M., CHAUDHRY M.N., AHMAD S.R., SAIF, S. MEHMOOD A. Performance of eia authority and effectiveness of eia system in pakistan. Environmental Impact Assessment Review. 81, 106357, 2020.

44. HUGHES A.C., LECHNER A.M., CHITOV A., HORSTMANN A., HINSLEY A., TRITTO A., CHARITON A., LI B.V., GANAPIN D., SIMONOV E., MORTON K., TOKTOMUSHEV K., FOGGIN M., TANMULLINS M.,. ORR M.C, GRIFFITHS R., NASH R., PERKIN S., GLÉMET R., KIM M., D.W. YU. Horizon scan of the belt and road initiative. Trends in Ecology \& Evolution. 2020. 